\title{
Information Technology Adoption and Related Policy Issues in Malaysia
}

\author{
Ali Shabanesfahani ${ }^{1}$, Mohammad Reza Faraj Tabrizi ${ }^{2}$ \\ ${ }^{I}$ Perdana School of Science, Technology and Innovation Policy, Universiti Teknologi Malaysia \\ ${ }^{2}$ International Business School, University Technology Malaysia
}

\begin{abstract}
This paper aimed to study the adoption of information technology in Malaysian Industrial sector. The author also investigates how government policy affected the adoption of information technologies. This paper provides national and international policy options to encourage the information technology adoption, which control influence, the productivity and innovation of the industrial sectors in Malaysia. Information technology plays a crucial role for the industrial sector to become more innovative and competitive. Such a contemporary technology may direct toward economic growth if it employed prevalently. It is very important for the country to adopt new technology but the decisions are made usually based upon the making comparison between potential advantages and costs of adoption for such a technology. Generally speaking, it is significant to apply the correct policy at the right time and place, so that the country can reap the benefit of adopting new information technology.
\end{abstract}

Keywords: Information technology, policy, economic growth

\section{Introduction}

Nowadays organizations have to increase their core competency and competitive advantage with an upward trend in order to sustain in the market. Therefore, they have employ new technologies and adopt themselves with the new system permanently. According to D'Aveni (1994) [8], this extensive form of competition among organizations is what so called hyper-competition. Besides, Nonaka and Takeuchi (1995) [17] proposed that such a competition could direct the organizations toward enhancement of innovation as a solution for establishing the constant competitive advantages. In accordance with number of studies (Barton, 1995; Grant, 1996) [3] because of such competitions, the need for increasing efficiency and prompt access to knowledge and information among organizations is vital. As a result, implementation and adoption of information technology (IT) has dramatically increased over the last years. Let's start with the question that what is the concept of Information technology and its innovation all about? And what is the government policy regarding adoption and assimilation of this technology? In the following part we will discussed about this technology elaborately.

\section{What Is Information Technology?}

Information technology is a field of engineering, which is derived from combination of computers and telecommunications science and "employed in stores in order to, retrieve, transmit and manipulate data" (Chandler et al.,2012) [5]. Besides, the IT Association of U.S has denoted it as "the study, design, development, application, implementation, support or management of computer-based information systems" (Daintith, 2009). [7] However, this terminology is prevalently employed as a substitute for computers and computer networks, but "it also surrounded by disparate information distribution technologies such as television and telephones" (Chandler et al.,2012). [5]

Less than two decades afterward the progress of the worldwide network, the globe faces a monumental digital divide. A little state has come to be quick adopters of the Internet, as the bulk lags distant behind. The rise of Information and Communication Technology (ICT), extensively trusted to be the foundation of an growing vision established area and its possible in enhancing the progress of a country's economy, has nowadays compelled countless states to understand the demand to contain ICT as a fourth dominant parameter of creation in an economy, separately from earth, labour and capital (Azzman 1997 - In the Star newspaper dated on September 2, 1997). According to (Osman, 2005) [18] Information and Communication Technology is described as an approach that involve all types of knowledge which is employed in order to craft, store, transact and retrieve Information in all forms. Information Communication Technology "engages computer-related technologies that are capable for Communication and the processing and transmission of Information through electronic way" (Osman, 2005). [18]

Many strategy makers and consultants seemed convinced that ICT requests have a momentous encounter on client ability enhancement, price reduction, and productivity enhancement in bestowing new dimensions in the marketing of produce and services (Fong, 2009; Pilat \& Wyckoff, 2005; Yavas, Luqmani, \& 
Quraeshi, 1992) [10] . On the macro level, governments in most states seem to trust that the use of ICT requests is additionally capable of enhancing the progress of a country's economy both internally and internationally. The above embody a little of the reasons that have stimulated the Malaysian government to allocate distinct attention to devise and apply assorted measures to enable the comprehensive uptake of ICT requests across the country. Portion of this is due to the stable belief grasped by the government that the comprehensive usage of ICT requests might enable in the progress of the country's economy, exceptionally in words of enhancing efficiency and productivity at the assorted sectors of the economy across the crucial usage of ICT applications. Information Technology as one of the crucial instruments could expedite the process of development in Malaysian economy in addition to improvement in human life. In Malaysia, it was tried by government to invest on IT infrastructure in a sixth step plan in order to put a pace forward in a comprehensive network. Therefore, incremental usage of IT in Malaysian public and private sectors has reinforced productivity and effectiveness in addition to competitive advantage of both groups (7th Malaysian Plan Report).

In relation to the quotation highlighted above, the government has given a number of programmes and projects to enthuse the wider diffusion and request of computer requests at the assorted sectors across the country. This can be perceived from the pursuing excerpts of the 8th Malaysian Plan report that reveals the eagerness of the government in reassuring a wider uptake of ICT requests amid its people. ICT diffusion and assimilation in Malaysian economy could provide a good chance in order to surge efficiency in addition to enhancement of competitiveness (8th Malaysian Plan Report). Such activities by Malaysian government not only in large city but also in rural area should aim to persuade people toward its adoption and try to improve people perception about Information Technology. Taking the open-minded arrangement of "Korea, Singapore, and Taiwan as superior economies of Asia-Pacific for analogy, the paper concentrates on the strategies for adopting technical established commercial growth in Malaysia". Illuminating on the prosperous experience in adopting technical established commercial progress, the aim of the research is to provide unique strategies for implementation of Information technology in Malaysia. Given that the progress of technical enhancement in Malaysia, it is obvious that previous strategies needs certain requirements and tools to build affirmative spillover from the MNCs that usually work in the production industry. Grasping a onward looking outlook Malaysia might main accord the change network ideal and colossal stable internationalization ideal in order to development the strength of the pillars of technology. The key agents like human capital, science and Technology, research \& progress, external Technology transfer and government research institutes will be investigated for rising progress of the technical events in Malaysia.

\section{Background of the Study}

Before 1990s, there were numerous papers mentioned to significant, innovative and vital role of Information Technology and its adoption in addition to optimistic view regarding IT's potential for creating core competency (Powell and Dent-Micallef, 1997) [20]. However, in present time, "there are some challenges toward previous optimistic views due to the appearing of empirical evidence which is explaining another story in concern with "productivity paradox" of IT". Although according Brynjolfsson (1993) [4], such a paradox is derived from the shortage of empirical studies regarding to positive influence of IT investments.

Besides, Malaysia as a growing economy in Asia-Pacific region is hopeful to "put step forward in application and adoption of technology-driven and high-tech production-based outline of development in order to imitate the successful experience of developed economies in Asia". As a matter of fact, according to Mani (2000) [15], "Malaysia is capable of having potential to craft new technologies on their own and can be clustered in category of countries who have it".

Although there was a tough financial crisis in 1997 in Asia, where all countries were engaged but the future outlook is very encouraging. This viewpoint shaped because of prompt technical enhancement of the developed economies from last two decades. (Hobday, 1995) [13]. Simultaneously, however Malaysia and these industrialized and economically developed countries located in the Asia pacific but to a great deal has a different economic and trade structures. Having considered these points, needless to say that Malaysia has a strong foundation to put step forward in order to make its own strategies for technical enhancement based upon what have been implemented in developed economies.

Martin and Matlay (2001) [16], Proposed that it is vital for organizations to implement diffusion and adoption of new technologies in order to survive in recent competitive environment. Current idea supported by study of Chaston et al., (2001) [6] which test the impact of moderating factors on IT through 180 SME in U.K (Chaston, Badger, Mangles, \& Sadler-Smith, 2001). From overall results, it was deduced that small firms are keener to adopt new ideas and easily change their vision in order to gain advantages that make them more competitive. Besides, in study by Ramsey et al., (2003) [22], it was mentioned that the important encouragement for SMEs to adopt ICT are in concern with potential advantages which is obtained from ICTs. The rise of Information and Communication technologies has altered and developed countless sectors. Malaysian 
government changed their economy from commodity-base to manufacturing-base with allocating larger emphasis on ICT (Haddon, 2004) [12].

Government came up with "one computer to each family" policy in order to make the peoples computer literate according to its K master plan. The Employee Provident Fund was utilized in order to arrange for funds for buying of PCs. This move was considered as the latest and positive movement by the government of Malaysia (Ramayah \& Muhamad, 2004) [21]. In Malaysia, government tries to create favorable condition that can create IT awareness in the peoples and attempts to create a climate that would encourage firms to become aware of the relevance of IT in their organization. Organizations that choose not to adopt any innovation are considered as non-adopters.

With considering current background, the diffusion and employing of Information and Communication Technology is extensively perceived as a core competency for companies in the growing globe environment. Besides, this context raises some questions including, "what is the awareness level of ICT amongst the owners of Malaysian Companies? What is the extent of ICT utilization amongst Malaysian industries? Are companies in Malaysia, using ICT sufficiently? What are the factors that make possible the adoption and use of ICT by Malaysian companies?" Consequently the goal of this paper is to scrutinize the level of consciousness regarding to Information and Communication Technology and criteria that could alter the implementation of online ICT amongst Malaysian companies (Selamat, Jaffar, and Kadir, 2011). [23]

\section{Problems Faced For Ict Adoption}

Even though, in Malaysia there are many local and multinational companies that depend on the technology to advertise their business or to enhance the product information to the customers, the adoption rate of Technology is still below satisfaction. There are many exemptions and tax incentives like (tax exemptions, modern infrastructures, globally completely tariffs and no import duties).(Tam) [24]

Nowadays, Information and communication technology is considered as a necessary tool in human life. Everybody without considering its gender in present society have to acquire knowledge about basic ICT skills to work in an accepted manner and effectively, in order to improve and make progress and triumph in their working lives. In terms of Malaysia, government takes technological policies in order to provide a constant incentive for innovation in technology and not just staying on adoption or diffusion of technology. According to Rosnah and Hashmi (2005), selection and implementation of such strategies can direct toward less adoption of technology. According to Rosnah, Megat and Osman, (2004) [18], however, Malaysian SMEs have wellbalanced information regarding to possible advantages of manufacturing technologies but regretfully these companies are suffered from lack of information about certain methods and approaches that technology can assist their businesses.

Edison \& Geissler, (2003) [9] Said that there is a tough process in order to know about the influence of technology on society and its members when it is overestimated. Technology affects everyone in the society as it changes the fabric and leads to expedite the process of economic development and innovation. (Turner, 1984) [25] Provided empirical studies and shows that "technology can potentially have impact on the nature of the work, job satisfaction, and the quality of work life." Thus as Agarwal and Prasad, (1999) [2] proposed that if the technology or system is not utilized effectively and efficiently may not provide an appropriate results.

(Tam) [24] Indicated that it is very difficult for an organization to adopt the new technology in replace of old technology very fast. Not all the companies can implement the new technology. It was found that there is always an eagerness in the people to adopt the new technology. In addition, the information system department needs an individual to adopt the new technology in order to make easy for the staff to use the system.

If we discuss in the field of agriculture, there are many problems associated with adoption of recommended farm practice: lack of capital, small farm size, availability of farm inputs, availability of marketing services, organization of the small farmers and availability of advisory services are some of the problems. These problems reflect the quality of advisory services provided to the small farmers. The main problem is "how much emphasis is given to adoption of recommended farm practices?" What practices should be adopted by the small farmers? How should it be organized at agency level and village level? How should it be evaluated? Answers to the above questions will help reduce problems associated with adoption of recommended agricultural practices by small farmers.

\section{How to Improve Policy-Making}

Although there are many years of constant study regarding to improvement of policy-making process but still the conventional views have not been changed. Besides still governments, politicians, and researchers keep on to assert their issues about the methods that policy is made and its upcoming issues. There is need for these issues to be scrutinized by "government as main power for making important policies, which is applied in a country. Besides it should be noticed that since these policies be unsuccessful, the costs in terms of monetary or other thing would be dramatic". 
It is significant to know why the majority of efforts for enhancing policy-making have unsuccessful to show and implement in real world. Since last decade, "there have been many attempts in order to reinforce the process of policy-making, from different perspectives of process, qualities, structures, and politics". Needless to say, "such efforts have suffered from a widespread distance between theory and practice". This failure occurred maybe due to implementation of unrealistic models of policy-making, or failure in making sufficient upholds for changing favorable practices into reality. Consequently, it should be mentioned that for turning to policy which is made both government and organization are responsible for its implementation and if any of them not be accountable, the policy making process will be directed toward failure and need their joint efforts.

However, sometimes these problems happen because of lack of access to information about visual problems by policy makers. "Policy makers in case any problem they have to fall back on their native wits and assemble ad hoc solutions to the problems that arise". Such shortages in empirical studies and a logical process in many cases "lead for leaders to take decision and choose policies by chance, personality, and individual skill". However, recently in some developed economies and industrial countries there are some evidence that this problem to some extend has been solved but still in many developing countries like Malaysia it is vital to implement a significant research to make a visual and coherent methodology to enhance the policy making process.

\section{Solutions For The Problems}

Organizations need to focus on the complexity issue before the adoption of new technology. If the problem to adopt new technologies becomes very high, then it is recommended to become a later adopter of technology instead of earlier adopters. Since earlier adopters have to deal with many partners and tend to received more pressure.

Government policies need to take into granted and there is requirement to adopt technology that is necessary for your organizations. There is a need of knowledge-based economy instead of technology based, as if there is no knowledge on technology usage, then that may incur high cost for the organization.

\section{Problems Should Systemically Be Solved}

However, flexible organizational process for pleasant policy-making is compulsory, but it is not enough individually. It should be aimed to design processes that not only show the main purpose of policymaking, but also tries to enhance those realities and provide an accurate process for implementation of that policy. This means that there is a significant need "to make policy process closer to the real world, and bring the real world closer to the policy process".

As a result, there is a requirement to commence for solving systemic problems that lead the following the current process become tough. However, there are number of companies that through developing some guidelines and mechanisms for their policy makers tried to solve the problem and show feedback to the environments. Although even providing such guidelines make it necessary for policy makers to develop their learning capability (Linder and Peters,1990) [14]. To some up, it is obvious that one of the "core issues is that in present time government has not sufficient capability or chance to learn from policy making process that needs to be addressed as soon as possible".

\section{A Comparative Study Between Application Of It Policy In Nordic Countries And Malaysia}

An illustrative example of the transformation of a service provision integrating public and private sector efforts regarding to implementation of information technology may be found in internet banking. Nordic banks were among the first in the world to adopt a large-scale shift towards Internet banking. Because banks charged high service fees for services provided at the counter (several euro per paid transaction), but offered the same or similar services free-of-charge on the Internet, customers quickly adopted internet-based banking. This led the banks to reduce the number of counter employees, and thus lower costs.

The integration of the financial sector into public administration is also evident in the identification process. The majority of online services provided by the public sector in Finland employ internet-banking codes. The public sector has long tried to create an in-house electronic identification system but having failed it has now adopted the readily established identification structure used by all the major Finnish banks. Malaysian government also need to try more to integrate financial sectors with public administration and tries more to persuade their people toward using banking system.

\section{Conclusion}

To sum up, having considered all the above-mentioned result, information technology likes any other technology has both pros and cons; however, government in order to help to prosperity of their economic need to adopt and assimilate information technology among organizations despite some of its adverse or paradoxical 
impact. Government through reviewing the successful countries in terms of implementation of information technology and learning useful lesson from them such as Finland in terms of application of IT in banking system or education sector or from U.S for other part can overcome to their obstacles.

However, it should be mentioned it is very easy to provide a policy on paper for country but the issue will rose when it is going to implement in real world. As a result, an accurate plan for implementation of it for Malaysian government is necessary.

\section{References}

[1] Azzman Sharifadeen, M.T. 1997. Creating an R\&D Culture, Building an Industry in Intech. In The Star,p. 38.

[2] Agarwal, R., \& Prasad, J. (1999). Are individual differences germane to the acceptance of new information technologies? Decision sciences, 30(2): 361-391.

[3] Barton, D.L. (1995). Wellsprings of Knowledge: Building and Sustaining the Sources of Innovation, Harvard Business School Press, Boston, MA.

[4] Brynjolfsson, E. (1993). “The productivity paradox of information technology", Comm. ACM, 35, 66-77.

[5] Chandler, Daniel; Munday, Rod, (2012). "Information technology", A Dictionary of Media and Communication (first ed.), Oxford University Press.

[6] Chaston, I., Badger, B., Mangles, T., \& Sadler-Smith, E. (2001). The internet and e-commerce: an opportunity to examine organisational learning in progress in small manufacturing firms? International Small Business Journal, 19(2): 13-30.

[7] Daintith, John, ed. (2009). "IT", A Dictionary of Physics, Oxford University Press, retrieved 1 August 2012 (subscription required)

[8] D'Aveni, R. (1994). Hypercompetition: The Dynamics of Strategic Maneuvering, Basic Books, New York, NY.

[9] Edison, S.W., \& Geissler, G.L. (2003). Measuring attitudes towards general technology: Antecedents, hypotheses and scale development. Journal of targeting, Measurement and Analysis for Marketing, 12(2): 137-156.

[10] Fong, M. (2009). Technology leapfrogging for developing countries. Encyclopedia of Information Science and Technology. Hershey, Pennsylvania: IGI Gobal, 3707-3713.

[11] Grant, R.M. (1996). “Toward a knowledge-based theory of the firm", Strategic Management Journal, 17( special issue): 109-23.

[12] Haddon, L. (2004). Information and communication technologies in everyday life: A concise introduction and research guide: Berg Publishers.

[13] Hobday, M. (1995). Innovation in East Asia: the challenge to Japan. Aldershot, London.

[14] Linder and Peters,(1990). 'An Institutional Approach to the Theory of Policy-Making', pp. 59-83.

[15] Mani, S. (2000). Policy Instruments for Stimulating R\&D in the Enterprise Sector. Policy, 9.

[16] Martin, L.M., \& Matlay, H. (2001). "Blanket" approaches to promoting ICT in small firms: some lessons from the DTI ladder adoption model in the UK. Internet research, 11(5), 399-410.

[17] Nonaka, I. and Takeuchi, H. (1995). The Knowledge Creating Company, Oxford University Press, Oxford.

[18] Osman, M.N. (2005). Information and communication technology policies in Malaysia:Analysis on government measures to minimise the digital divide. Palm Garden Hotel IOI Resort, Putrajaya.

[19] Pilat, D., \& Wyckoff, A.W. (2005). The impacts of ICT on economic performance: An international comparison at three levels of analysis. Transforming enterprise: The economic and social implications of information technology, 77-110.

[20] Powell, T.C. and Dent-Micallef, A. (1997). “Information technology as competitive advantage: the role of human, business and technology resources", Strategic Management Journal, 18(5): 375-405.

[21] Ramayah, T., \& Muhamad, J. (2004). Technology Acceptance: An Individual Perspective. Current and Future Research in Malaysia. Review of Business Research, IABE, 2(1), 103-111.

[22] Ramsey, E., Ibbotson, P., Bell, J., \& Gray, B. (2003). E-opportunities of service sector SMEs: an Irish cross-border study. Journal of Small Business and Enterprise Development, 10(3), 250-264.

[23] Selamat, Z., Jaffar, N., \& Kadir, H.A.(2011). ICT Adoption in Malaysian SMEs.

[24] Tam, L.Y.K. The Critical Success Factors that Influence Organizations to Adopt Internet Technology. Malaysian Journal of Library \& Information Science, 6(2)

[25] Turner, J.A. (1984). Computer mediated work: the interplay between technology and structured jobs. Communications of the ACM, 27(12), 1210-1217.

[26] Yavas, U., Luqmani, M., \& Quraeshi, Z.A. (1992). Facilitating the adoption of information technology in a developing country. Information \& management, 23(2), 75-82. 